\title{
From Petrus to Pontifex Maximus
}

\author{
John R. Curran
}

The peculiar journey of the title pontifex maximus from emperor to bishop of Rome has been the subject of numerous scholarly treatments. ${ }^{1}$ The title's imperial echoes lent to the Renaissance bishops of Rome a grandeur that reflected their ambitions as leaders of their church and as patrons of a city being re-born. As is clear now, however, that journey was by no means as straightforward as was once thought. Above all, scholars have sought to identify when precisely and to what extent the title was laid down by the emperors. Only recently has serious attention been paid to the actual attractions of the title to its Christian holders. The title pontifex and, ultimately, pontifex maximus has been characterized as an anchor that permitted a change of orientation in the religious, cultural and political life of late Rome by maintaining a crucial connection to a distinguished past. ${ }^{2}$ It will be suggested here, however, that there is more to be said about the nature of this anchoring. To appreciate it fully requires something of a re-calibration of the enquiry, however. Specifically, it requires the simultaneous examination of ancient perceptions of the responsibilities of those who led the early Christian communities alongside those who oversaw the religio of Rome. This in turn challenges us to re-calibrate as well our conception of claims made about Peter himself, perceptions of his identity and the development of claims to primacy made by the later bishops of Rome.

Unlike sectarian Judaism, the movement around Jesus came to require apostoloi, bearers of his teaching. Discipleship was not enough. The synoptic Gospels record the commissioning of the Twelve as 'apostles' to the settlements of the region with news of the coming Kingdom. ${ }^{3}$ Luke adds the 'sending out' of 70

1 The most significant interpretations conveniently summarised in Dijkstra and Van Espelo (2017) and also Kajanto (1981). See also Hekster's contribution to this volume.

2 Dijkstra and Van Espelo (2017).

3 Matt. 10.1-15; Mark 6.7-13; Luke 9.1-6. 
or 72 'others.' With the releasing of the 'Spirit' after the resurrection of Jesus, however, yet others who had not been disciples perceived themselves to be 'apostles' - most famously Paul of Tarsus. From the outset there was thus an inherent tension between the varying claims to mission. In his first letter to the Corinthians, Paul famously defended attacks upon his legitimacy: 'Am I not an apostle? Have I not seen Jesus our Lord? Are you not my work in the Lord? If I am not an apostle to others, at least I am to you; for you are the seal of my apostleship in the Lord. ${ }^{5}$ In his second letter, Paul identified 'super apostles' (ton huperlian apostolon) 'Hebrews', 'Israelites', 'Abraham's Seed' by whom he felt challenged (he hoped they would castrate themselves). ${ }^{6}$ He himself denounced 'false apostles.7 The very real tensions of this world explain the distinctive accusation of Clement of Rome that Peter and Paul had both been the victims of 'jealousy [phthonon] and envy [zelos]'.

It is clear, however, that there were overseers of Christian communities whose status was not that of apostles. Paul's letter to the Philippians, written in the early 5os, was addressed to 'all the hagioi ['saints', 'holy'] of Christ who are in Philippi with (sun) the episkopoi and diakonoi. ${ }^{9}$ Understandably, these figures, important though they clearly were, did not - indeed could not have the prominence of apostles in Paul's correspondence. But by the time of the pseudonymous First Letter of Paul to Timothy, written in the last years of the century, the episkopos had become the subject of much more attention. While preserving some of his Pauline characteristics, in particular the requirement that he manage 'his own household (oikos) well', the episkopos had become a figure who needed to be 'skilful in teaching' (didaktikon). ${ }^{10}$ 'Timothy' himself was urged to remain in Ephesus where there was a threat from 'myths and endless genealogies that promote speculations rather than the divine training (oikonomia) that is known by faith.'1

The developing identity of the episkopos is important. As Chilton and Neusner have characterised it, the movement was changing. The 'myths and

$10 \quad 1$ Tim. 3.1-4. Chilton and Neusner (1999) 59 thought the term meant 'interpretative, magisterial instruction on the basis of the Scripture of Israel'.

$11 \quad 1$ Tim. 1.4.
} 
genealogies' of Paul's First Letter to Timothy may be a reference to the genesis of the more extensive records that transformed Christianity from its original experiential nature to something much more exegetical..$^{12}$ Some of these texts (above all those that were to constitute the New Testament) promoted Jesus as a teacher (didaskalos), admittedly, according to Geza Vermes, of a particularly provocative and unconventional type, but whose teachings required close examination. ${ }^{13}$ The same began to happen to the apostle Peter. In his recent study of depictions of Peter in the apostolic fathers, Todd Still drew attention to the second-century testimony of Papias of Hierapolis, according to whom Peter had been an inspired and engaging teacher whose listeners had prevailed upon 'Mark' to set down a record of his teaching, and the document that resulted had been written in Rome. ${ }^{14}$ In the same spirit, and doubtless derived from much earlier Christian texts, Eusebius of Caesarea characterized James the brother of Jesus as the first 'episkopos' of Jerusalem, an authority figure, and a depiction consistent with the New Testament's account of Peter, Paul and James in dispute over the Law. ${ }^{15}$

Those searching for concrete evidence of Peter in first-century Rome find little to work with but a search of this kind risks overlooking what were the actual priorities of earliest Christianity. In these years, the residence of apostles was of much less consequence than encounter with them. As the eschaton receded and the Jesus-generation passed away, however, diverse documents and the persisting Jewish Law brought the demand for exegesis and authority in teaching.

If we return to that accusation in The First Letter to Timothy against the teaching of Paul, one of the charges levelled at the opponents was that of promoting 'endless genealogies' (geneologiai). ${ }^{16}$ Luke and Matthew, as well as their near contemporary Flavius Josephus, all included genealogies in their presentation of the authority of their respective knowledge. ${ }^{17}$ In the second- and thirdgeneration communities which had hosted apostles of Jesus, 'genealogies' in the sense of the deliberate invocation of the authority - over and above their teaching - of apostles in particular places, of the succession of ecclesial leaders also began to appear. According to Zwierlein, the first clear evidence for

12 Chilton and Neusner (1999) 58.

13 For Jesus as a Jewish teacher, see Vermes (2003) 27-8.

14 Eus. $H E$ 2.15.1-2 [= 'Papias 2' in Ehrman]. The 'Markos' of 1 Clem. was the same 'Mark', according to Papias (apud Eusebius, loc. cit.). See Still (2015), 165-6.

15 Gal. 2.11-21; Acts 15. Eusebius perhaps depended on Clement's Hypotypoesis: HE 2.1.2-3; 7.19.

161 Tim. 1.4.

17 Jos., $A J$ 2.176-83 on the sons of Jacob. 
the assertion that Peter had resided in Rome was provided by Justin Martyr in the middle years of the second century. ${ }^{18}$ At around the same time, as George Demacopoulos has shown, more biographical treatments of Peter in the city began to appear in apocryphal $a c t a .{ }^{19}$ Irenaeus, arguing that adherence to the true gospels and apostolic tradition that came through apostolic succession guaranteed right thinking, described Peter and Paul identifying and ordaining successors. ${ }^{20}$ And the Memoirs of Hegesippus reported that he had travelled widely and learned exactly the same teaching from all bishops: 'being in Rome I made for myself a succession as far as Anicetus.' ${ }^{21}$ Eusebius preserved a statement from Dionysius of Corinth, writing around the same time as Justin, that Peter and Paul together were the 'founders' (phutusantes) of the community there. ${ }^{22}$ Origen named Ignatius as the second episkopos of Antioch and Eusebius conveyed the identification of Peter as his predecessor. ${ }^{23}$

The famous report of the Roman presbyter Gaius that tropaia could be seen on the Via Appia and at the Vatican Hill comes, significantly, from the same mid-second century period and is, I think, to be understood as a topographical manifestation of the same process of formally connecting Christian communities to apostles. ${ }^{24}$

\section{'Every Church Should Agree with This Church on Account of Its Pre-Eminent Authority'25}

This more explicit memorialization of apostles in particular places came to impinge on the process of problem-solving. Cyprian's relationship with the bishop of Rome has, in the past, been characterised as a phase in the development of Roman papal primacy; a battle of wills to impose the power of Roman

\footnotetext{
18 Zwierlein (2010) 128-33.

19 Demacopoulos (2013) $16 \mathrm{ff}$.

20 Adv. Haer. 3.3.2-3 with Gwynn (2012) 879. Cf. Tertullian, Prescriptions against the heretics 32: 'Let them [the gnostics] produce the original records of their churches; let them unfold the roll of their bishops, running down in due or succession from the beginning in such a manner as that first bishop of theirs shall be able to show for his ordainer and predecessor someone of the apostles or of apostolic men'. Note that Irenaeus also talks about successions of presbyters (3.2.2). Irenaeus also singled out Smyrna as an apostolically founded church, Polycarp having been ordained by John: Adv. Haer. 3.3.4.

21 Eus. $H E$ 4.22.3. (c. 165).

$22 \quad H E$ 2.25.6.

23 Origen, Hom. In Luc. 1; Eusebius, HE 3.36.1.

24 Eus. $H E$ 2.25.6-7.

25 Irenaeus, Adversus Haereses 3.3.2.
} 
Christianity. But more recent scholarship has invited us to see that relationship as much more extensive and dynamic, irreducible to a straightforward standoff between Rome and Carthage. ${ }^{26}$

According to Demacopoulos, Cyprian's understanding of the reference to the commissioning of Peter as portrayed in Matthew 16 allowed him both to acknowledge the Petrine tradition of Rome but at the same time to emphasise the leadership required of every bishop in his own church, declaring that 'the episcopate is one. ${ }^{27}$

The correspondence between Cyprian and a number of bishops of Rome reveals him to be, just as he repeatedly states, in fraternal contact with the bishops there. Deciding to report the outcome of the African synod of 253 (at which the lapsi were readmitted to the church) Cyprian was not seeking approval but offering views that he hoped might shape practice in Rome. ${ }^{28}$ His crucial fifty-fourth letter, outlining to Cornelius of Rome recent trouble in Africa, had been sent in response to the suggestion that information requiring correction was circulating in Rome. And Cyprian's correspondence shows bishops of diverse places writing to a number of other bishops about the same issues; Faustinus of Lyons, for example, wrote to both Cyprian and Stephen of Rome about the illegitimate installation of Marcianus and a collection of Spanish bishops sought Cyprian's opinion in contrast to that expressed by the bishop of Rome. ${ }^{29}$ Only the controversy over re-baptism prompted the startling suggestion that Rome's apostolic heritage was being misrepresented by bishop Stephen - not that an active primacy was being asserted..$^{30}$

As Geoffrey Dunn has put it, however, the search for papal primacy is a distraction from our appreciation of Cyprian's broader context: 'scholars have turned to Cyprian's treatises to determine his theology of papal ministry in isolation from the practical realities of how he related with the Roman church' an important observation to which I shall return. ${ }^{31}$

26 Above all, see Dunn (2007).

27 Ep. 33; de unitate 4-5. Cf. Ep. 59 on Felicissimus travelling to 'the throne of Peter, the chief church in which priestly unity takes its source'. See Demacopoulos (2013) 27-28; Bockmuehl (2015); Dunn (2007) 192.

28 Ep. 56 with Dunn (2007) 102-6; 195-6.

29 Ep. 68 with Dunn (2007) 120-3; Ep. 67 with Dunn (2007) 125-33.

3o Ep. 74.6 (from Firmillianus, bishop of Caesarea in Cappadocia): 'they who are at Rome do not observe those things in all cases which are handed down from the beginning, and vainly pretend the authority of the apostles ....

31 Dunn (2002) 243 . 
One of the most enduring assumptions in the scholarship on Constantine is that the advent of a Christian emperor and the full and formal legalization of Christianity were each universally welcomed by Christians. At Rome, unprecedented resources became available to the Christian community: imperial land, revenues and an army of workers to construct the Roman churches of the new Constantinian dispensation. The emperor himself was a dramatic manifestation of God's willingness still to intervene in the world of men and Constantine became an enthusiastic advocate of the faith. The bishops of Christianity in particular now had behind them a patron who would propel them into the front rank of public affairs.

In the first place, there is in fact no reason to think that the Christian community, if left to its own devices, would ever have invented the oecumenical council. As we have seen, while apostolic claims had entered the discourse between bishops in dispute, synodal decisions and letters of communion actually constituted a serviceable system of governance. The oecumenical council amplified the apostolic claims of individual communities to an ecclesiologically deafening level. ${ }^{32}$ The bishops of Rome were faced with the choice of having consciously to down-play their apostolic claims or formally to assert them on a world-wide scale. Sylvester, perhaps sensing the danger and as he had done with Constantine's council of Arles, deftly excused himself from participation. ${ }^{33}$

Second, and in the case of Rome specifically, the 'material establishment' of Constantine was arguably a challenge to the centuries-old Christian facilities of the city. One of the blind-spots of scholarship on fourth-century Rome is its misplaced confidence in reading maps of the distribution of the Christian churches of the city. Plotting the position of churches and attempting to deduce the pace of construction or the visibility of the results overlooks the fact that there was a distinction between what bishops of the city were attempting to do and the plans of emperors. ${ }^{34}$ It is clear that the milieu of the bishop was where it had always been - in the parishes of the city.

32 And Constantine optimistically declared their decisions to be both divinely inspired and legally binding. See Barnes (2014) 133.

33 Eus. VC 3.7.2 (and Soz. HE 1.17) citing Sylvester's excuse of old age. He actually lived on for another 10 years. See Pietri (1976) 173-4.

34 For 'slow' pace of building: Bowes (2008) 62; on the 'virtual invisibility' of the churches c. 350: Brown (2012) 246. Thompson (2015) 30 offers a correction in highlighting the role of Roman bishops in shaping the ecclesiastical landscape. Cf. the contribution by Friedrichs on old Saint Peter's in this volume. 
Third, from perhaps as early as 318 , correct belief became christiana lex. ${ }^{35}$ Unlike the innovation of the oecumenical council, belief as lex made available to the Christian community a great ready-made system of problem-solving: the body of Roman law and its institutions. But as Caroline Humfress has observed, the Christian problems could be a rough enough fit with historic Roman legal concepts: 'the prosecution of illicit Christian behaviour was undertaken through appeals to the same rubrics of criminal law' ${ }^{36}$ Heresy, for example, became a crimen publicum; defence of the 'sacrosancta ecclesia catholica' was a defence of the state itself. ${ }^{37}$ Maleficium became the charge against heretics from the Manichees to Priscillian. ${ }^{38}$ For Arcadius and Honorius the Eunomian and Montanist heresies were superstitiones; Nestorius would be condemned in the same terms. ${ }^{39}$ And Leo the Great would end up denouncing Priscillian as the heir to the magi and mathematici. ${ }^{40}$

But one ancient Roman institution more than any other has attracted the attention of historians of the transition from pagan to Christian: the office of the pontifex maximus. ${ }^{41}$

At about the same time that the first of the written Christian gospels was being conceived, Vespasian was receiving formally the powers that would install him as the successor of the most legitimate Julio-Claudians. The 6th surviving clause of the famous lex de imperio Vespasiani conferred upon him the right to do whatever things divine, human, public and private [that] he deems to serve the advantage and the overriding interests of the state. 42 The one title that more than any other signified his capacity to deal with res divinae was pontifex maximus.

Possession of the title, as is well known, was for long considered the highwater mark of Christianity's supercession of paganism. An older generation of scholars believed that the bishops of Rome, beginning with Damasus or

\footnotetext{
35 CTh 1.27.1 with Edwards (2015) 195. Cf. 16.5 .1 for lex Christiana.

36 Humfress (2000) 129.

37 Idem.

38 Humfress (2000) 136-8.

39 CTh 16.5.34 (March 398); CTh 6.5.66 (435).

$40 \quad$ Ep. $15[P L 54$ c 679a] from 447.

41 See also Hekster's contribution to this volume.

42 CIL 6.930.
} 
Siricius, had taken it for themselves after a dramatic repudiation of the title in an interview between Gratian and his fellow pontifices, reported by Zosimus.

Modern scholarship has comprehensively overturned the idea. ${ }^{43}$ No credible evidence suggests that any late antique bishop Rome declared himself to be pontifex maximus. According to Liro Kajanto, the first unambiguous attestation of the title being used by the bishop of Rome was under Pope Eugenius (1431-1447) or, more likely, Nicholas V (1447-1455) ${ }^{44}$ As with the acquisition by the Christian god of the epithets of Jupiter (deus, optimus, maximus) at around the same period, the Renaissance popes' appropriation of the title was a classicizing, humanist phenomenon, an expression of cultural and political confidence and aspiration.

Scrutiny has recently returned, however, to the controversial passage of Zosimus. ${ }^{45}$ The latest attested Roman emperors bearing the title were Valentinian, Valens and Gratian, memorialized on an inscription of $369 \mathrm{CE}{ }^{46}$ According to Zosimus, Gratian repudiated the title as 'not lawful for a Christian' and no emperor can be found holding it again. A pair of recent essays published by Alan Cameron, however, makes it clear that the imperial title pontifex did in fact survive but it was now qualified by the adjective 'inclytus/inclitus', suggesting that Gratian had not comprehensively rejected the title but had, in the words of Cameron, 'redefined his priestly authority in less specific terms'. ${ }^{47}$ Cameron considered the adjective inclytus to be 'an entirely unspecific, uncontroversial epithet'. 48 Zosimus is accordingly to be disregarded as a disingenuous, partisan and incompetent witness.

But Cameron and others have struggled to work out precisely why matters should have come to a head during the reign of Gratian. This is because they have not considered who precisely the Christian pontifex was.

In reviewing the history of the title in the period after Augustus, Cameron pointed out that the pontifex maximus 'had no authority over the other colleges' which was why Augustus was careful to make himself a member of each

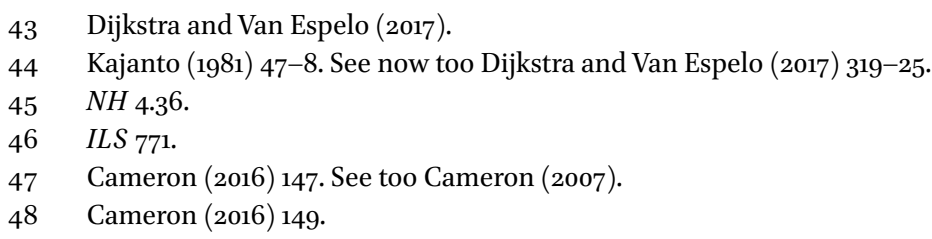


and every one of them. ${ }^{49}$ It is worth reflecting, however, on the historic responsibilities of the college of pontiffs. Among their duties they, under the oversight of the pontifex maximus, attended to the state's calendar, ruled on adoptions, wills and family law, and kept records of significant events. In the words of Beard, North, and Price: 'many of their functions shared a concern with the preservation, from past time to future, of states and rights within families, within gentes and within the community as a whole - and so also the transmission of ancestral rites into the future' - a summation of the very extensive responsibilities of the position..$^{50}$

The Greek translation of Augustus' res gestae rendered his title 'pontifex maximus' as archiereus. ${ }^{51}$ The same term (and the very similar archierea) appears in both the New Testament and Clement of Rome's first letter applied to the High Priest of the Jews. ${ }^{52}$ Like the pontifex maximus, the High Priest of the Jews stood in closer proximity to the divine, most solemnly illustrated in Jewish worship in the High Priest's role on the Day of Atonement when he alone of all Jews was permitted to enter the Holy of Holies in the Jewish Temple. ${ }^{53}$ According to E. P. Sanders, the Jewish High Priest was 'in some respects ... only "first among equals", just like the pontifex maximus. ${ }^{54}$ But what some historians have failed to appreciate is that attendant upon their elevated position both the high priest of the Jews and the pontifex maximus presided over, and themselves participated in, the regulation and appropriate application of religious law - a very real and routine task. ${ }^{55}$

In the case of the pontifex maximus, one prominent current idea is that the role is to be played down. ${ }^{56}$ Françoise Van Haeperen pointed out that the pontifex maximus could not exercise his power outside of Rome, but it is to be remembered that that did not stop Pliny consulting Trajan, as pontifex maximus, several times on points of pontifical law. ${ }^{57}$ And in $130 \mathrm{CE}$, petitioners to the college of pontifices under the presidency of the pontifex maximus sought his permission to transport into Italy a corpse from overseas. ${ }^{58}$ Fergus Millar has

49 Cameron (2016) 139.

50 Beard, North, Price (1998) 26.

$5^{1} \quad R G$ 4.7.

$52 \quad$ NT: Matt. 26.23 cf. 1 Macc. 13.42; 1 Clem. 36.1.

53 Day of Atonement: Sanders (1992) 141-3; Schürer II (1979) 275-6.

54 Sanders (1992) 327 .

55 See Grabbe (2010) 45-6: 'although there may have been legal experts who were laymen, the priesthood was still accepted as the custodians and interpreters of the law'.

56 See now Rüpke (2014) 233-53 with Cameron (2016) disagreeing.

57 Van Haeperen (2003) 138. Pliny, Epp. 10.49-50; 68-9. See Ando (2007) 443.

$5^{8} I L S$ 1792. Cf. ILS 1685 for permission granted 'permissu imp.' (seemingly M. Aurelius) for the transport of a dead man's remains to Italy from a northern province. 
traced the third-century imperial practice of issuing subscriptiones showing how emperors personally took responsibility for queries on aspects of sacred law. ${ }^{59}$ And, famously, Constantine's decision to re-shape the Vatican necropolis, a serious matter of obvious interest to pontifical law, was certainly facilitated by the emperor's position as pontifex maximus. ${ }^{60}$ The relative enthusiasm of individual emperors for the duties is not the issue in this context; nor is the extent to which Roman religio might be observed outside of Rome. What is significant is that the mechanism for consultation clearly persisted.

These ancient institutions, the High Priesthood of the Jews and the pontifex maximus of Rome, and, more specifically, the responsibilities of the posts, help to explain the attractiveness of the term pontifex for early Christians using Latin. In Paul's letter to the Hebrews Christ himself is 'a great high priest who has passed through the heavens' but the context is that of the judgement of God. ${ }^{61}$ And the First Letter of Clement, in a passage that some read as referring to an incipient Christian clerical system, mentions 'special liturgical rites' (idiai leitourgiai) that have been assigned by 'the Master (despotes)' to the 'high priest (archiereus)' over and against the tasks of 'regular priests' and 'Levites.'62 In the late second or early third century, when these letters were finally translated into Latin, the term archiereus was rendered, quite naturally, as pontifex. ${ }^{63}$

Tertullian, in portraying Christ as a new dispensator of a new Law, referred to him as the authenticus pontifex dei patris and praeputiati sacerdotii pontifex. ${ }^{64}$ Famously, Tertullian was the first to use the term to signify the Christian episcopus. In a much-discussed passage of his de pudicitia, written in 210 or 211, Tertullian denounced an episcopus episcoporum, scilicet - 'doubtless a' - pontifex maximus, who had issued a decree (edicit) offering forgiveness for sins of adultery and fornication. ${ }^{65}$ Much discussion has taken place over who precisely this pontifex maximus was, and if he is to be identified as the bishop of Rome, does the reference prove that the bishops of the city were

59 Millar (1977) 361: '... what is made clear by the various subscriptiones of the third century is that by then the emperor in person was giving answers on such questions [sacred law] to individuals ....

6o Heid (2007) 412. For later laws regarding tombs, see Curran (2000) 187-88 with Rüpke (2014) 246 denying the relevance of the position of pontifex maximus.

61 Heb. 4.14-16: Habentes ergo pontificem magnum, qui penetravit caelos ... non enim habemus pontificem qui non possit compati infirmitatibus nostris.

$62 \quad$ 1 Clement 40.5 with Kajanto (1981) 40.

63 Kajanto (1981) 38 and note pontificatus for to hierateuein.

64 Adv. Marc. 4.35.7 (CC 1.640); 5.9.9 (CC 1.69o).

65 De pudicitia 1.6. See Kajanto (1981) $44-5$ on the 'spiteful irony' of the reference. Barnes (1971) 141 argues for the bishop of Carthage as the pontifex maximus in question. For general discussions see Brent (2010) 319-20; Brent (1995) 503-35. 
already being attracted to the title? As we have seen, we lack the testimony to answer the latter question affirmatively. The much greater significance of the passage, however, is that it set the Christian episcopus alongside the pagan pontifex and did so precisely as we should expect, in the context of issuing rulings on the application of religious law. It is not, therefore, that the Latin pontifex is a simple translation of the Greek archiereus; it was a reflection of the similarities between the roles of each in adjudicating the laws governing appropriate religious behaviour.

In the 270s, when Aurelian was petitioned by the enemies of Paul of Samosata at Antioch, he made a ruling between them that attracted the praise of Eusebius for its equity. ${ }^{66}$ It would be extraordinary if the Latin-speaking emperor and his staff did not perceive that the various episkopoi were at issue over the interpretation of their own religious law; they were in fact identifiably 'pontifices'.

Following Constantine's conversion, with Roman law now, as we saw, considering proper/orthodox Christianity to be lex, the formal term pontifex for a Christian bishop was another of these formal legal 'fits' to which Caroline Humfress has drawn our attention. Constantine's famous remark that he too was a bishop, but of those 'outside' the church, reflects his perception of the similarities between his responsibilities as pontifex maximus and the bishops' own as pontifices of Christianity. ${ }^{67}$ This is the context in which to understand Constantine's granting of a judicial role to bishops, from the granting of asylum rights to the full-blown episcopale iudicium. ${ }^{68}$ By 360 if not before, the bishop of Rome was routinely being called pontifex Urbis Romae or pontifex summus. ${ }^{69}$ The title was one more indication of his growing confidence and influence. Michele Maccarone has drawn attention to the prominence of Roman episcopal authority that reached a new pitch with the deployment of the term sedes apostolica for the first time in 354 in a letter of bishop Liberius of Rome to Eusebius of Vercelli. ${ }^{70}$ Bishops at the council of Serdica wrote to bishop Julius of Rome ad caput, id est ad Petri apostoli sedem and the term moved smoothly into the vocabulary of Damasus. ${ }^{71}$ Siricius' letter ad Gallos was couched in

66 Eus. HE 7.29.1-30.19. See Millar (1971); Watson (1999) 188-98.

67 Eus. $V C$ 4.24. See Angelov (2014).

68 CTh 1.27.1 (318) with Gwynn (2012) 881-2.

69 Liberius as pontifex: Coll. Av. 2 p. 1.1 (Gunther's edition); Damasus: Pietri (1976) 1607 .

$70 \quad$ Maccarone (1991) 280; PL 8.1350B.

71 The letter Quod semper 1 (9): CSEL 65.127. Damasus: PL 13.582A (a report to Gratian and Valentinian on the Roman synod held under Damasus' authority): praerogativa tamen apostolicae sedis excellit and Epigram 57. The synod of 378 used the term "apostolic see" for the first time. See Chadwick (2001) 318. 
'imperious' language and its contents led Pietri to believe that the letter laid claim to the rights of a western patriarch. ${ }^{72}$ The coalescence of the two claims (to 'pontifical' status and to occupation of the sedes apostolica) was dramatically signalled by the famous law of February 380 : 'It is Our will that all the peoples who are ruled by the administration of Our Clemency shall practice that religion which the divine Peter the Apostle transmitted to the Romans, as the religion which he introduced makes clear even unto this day. It is evident that this is the religion that is followed by the pontifex Damasus and by Peter, episcopus of Alexandria, a man of apostolic sanctity. ${ }^{73}$ The clear ranking of the two bishops was the emperors' recognition of the public claims of the bishop of Rome.

But the rising profile of the Christian pontifex of Rome posed a clear dilemma for the emperors; specifically, the situation made the imperial title of pontifex maximus look somewhat anomalous. Being a pontifex maximus threatened to suggest that the emperor had some kind of superior rank with regard to the bishop of Rome, now calling himself (among other things) pontifex. But the emperor's title was historic and there were still duties attendant upon it. The famous episode reported by Zosimus of Gratian's repudiation of the title and Cameron's discovery of the post-Gratianic title of pontifex inclitus for emperors into the fifth century was the solution adopted to resolve the delicate situation.

Cameron is unsparing on Zosimus, dismissing his account as without any factual merit, except in the sense that it conveys that something happened under Gratian. ${ }^{74}$ But it is to be remembered that for several years at the beginning of his reign Gratian was content to bear the title. ${ }^{75}$ Why did he change his mind? His withdrawal of state subsidies from the ancient cults sometime in 382 suggests an evolving policy, a dramatic deviation from ancient practice. This development was of much greater historical import than the removal of the Altar of Victory, and it would be extraordinary if the pagan senators of Rome were content to accept it without representation. Zosimus' story, however garbled, records a solemn appeal to the emperor Gratian designed to clarify his commitment to the ancient religious traditions of Rome. Cameron argued that the 'pontiffs' mentioned by Zosimus cannot have offered Gratian a priestly robe because the pontifex maximus did not wear one is on the one hand

72 'un tono piu imperioso': Maccarone (1991) 291. Pietri (1976) vol. 1.772.

73 CTh 16.1.2, an edict to the people of Constantinople. See also Dijkstra's contribution to this volume, p. 6 (including Latin text).

74 Cameron (2016) 150-1; Cameron (2007) 366: 'there is scarcely a word of truth or fact in Zosimus' entire account'.

For the dating of the episode, see Cameron (2016) 154-5. 
historically unlikely and on the other, even if accepted, does not rule out the possibility of a defiant offering of an appropriately clean robe for performing religious duties. Similarly, the idea that pagan senators would not have risked a rebuff from a Christian emperor denies the historical possibility of any kind of principled and courageous act in the face of autocracy then, or, indeed, now. In short, Lellia Cracco-Ruggini is right: there was some kind of deputation to Gratian and it courageously forced upon the emperor an historic clarification of his position with regard to the position of pontifex maximus. ${ }^{76}$

\section{Conclusions}

In general terms, the enquiry into the final destination of the title pontifex maximus has been conducted with teleological enthusiasm; it has in large part been the search for an agreed terminus; whether post or ante. Much less attention has been paid to some important processes along the way. The case advanced in this paper suggests that some familiar working assumptions require re-visiting. It is time, specifically, to move beyond the idea that the title was a simple 'translation' of or 'equivalent' to titles of office-holders in the Greek-speaking church. As Dennis Trout has shown, the title pontifex was only one of a number of titles claimed by the bishops of Rome, as elsewhere. ${ }^{77}$ It is likely, as with the title pontifex, that these titles were not carelessly chosen and that we are now invited, much in the rather under-appreciated spirit of Charles Pietri, to look more closely at the bishops of Rome at work. ${ }^{78}$ The implications for the concept of 'anchoring' are significant. The discourse that achieved the anchoring was the product of labour as well as the conceptualisation of historic cultural and religious institutions, a valuable indication that the process had a number of different dimensions. The idea that this work was unimpeded by the patronage of Constantine is another serious assumption. In fact, the emperor's sponsoring of the Roman bishop may have made an unwelcome and counter-productive contribution to the often uncomfortable Christian discourse on the relative authority of Peter's successor. And it is time, finally, to relocate the courage of the last pagans of Rome away from the passionless relationes of Symmachus to the purveyors of the robes of the real pontifex maximus of Rome.

\footnotetext{
76 Cracco Ruggini (2009) 368: 'probabilmente con deliberato intento propagandistico'.

77 Trout (2015) 221 for Damasus as, variously, antistes, rector and sacerdos.

78 See Pietri (1991) 220 for misgivings about 'secularised' historical outlooks.
} 


\section{Bibliography}

Ando, C. 2007. Exporting Roman Religion. In A Companion to Roman Religion, ed. J. Rüpke, 429-45. Oxford: Blackwell.

Angelov, A. 2014. Bishop over "Those Outside": Imperial Diplomacy and the Boundaries of Constantine's Christianity. GRBS 54: 274-92.

Barnes, T. D. 2014. Constantine: Dynasty, Religion and Power in the Later Roman Empire. Chichester: Wiley-Blackwell.

Barnes, T. D. 1971. Tertullian: a Historical and Literary Study. Oxford: Clarendon Press.

Beard, M., J. A. North \& S. R. F. Price. 1998. Religions of Rome. Cambridge: Cambridge University Press.

Bockmuehl, M. 2015. Scripture's Pope Meets von Balthasar's Peter. In Peter in Early Christianity ed. H. K. Bond and L. W. Hurtado, 321-40. Grand Rapids, Michigan: Eerdmans.

Bowes, K. D. 2008. Private Worship, Public Values, and Religious Change in Late Antiquity. Cambridge: Cambridge University Press.

Brent, A. 2010. Cyprian and Roman Carthage. Cambridge: Cambridge University Press.

Brent, A. 1995. Hippolytus and the Roman Church in the Third Century: Communities in Tension Before the Emergence of a Monarch-bishop. Leiden: Brill.

Brown, P. R. L. 2012. Through the Eye of a Needle: Wealth, the Fall of Rome, and the Making of Christianity in the West, 350-55o AD. Princeton: Princeton University Press.

Cameron, A. 2016. Pontifex Maximus: From Augustus to Gratian - and Beyond, in Emperors and the Divine - Rome and its Influence, ed. M. Kahlos, 139-59. Online: http://hdl.handle.net/10138/161331.

Cameron, A. 2011. The Last Pagans of Rome. Oxford: Oxford University Press.

Cameron, A. 2007. The Imperial pontifex. HStClPh 103: 341-59.

Chilton, B. \& J. Neusner. 1999. Types of Authority in Formative Christianity and Judaism. London: Routledge.

Chadwick, H. 2001. The Church in Ancient Society: from Galilee to Gregory the Great. Oxford: Oxford University Press.

Cracco Ruggini, L. 2009. Pontifices: un caso di osmosi linguistica. Cristianesimo nella storia 31: 363-84.

Curran, J. R. 2000. Pagan City and Christian Capital: Rome in the Fourth Century. Oxford: Oxford University Press.

Demacopoulos, G. E. 2013. The Invention of Peter: Apostolic Discourse and Papal Authority in Late Antiquity. Philadelphia: University of Philadelphia Press.

Dijkstra, R. \& D. van Espelo. 2017. Anchoring Pontifical Authority: A Reconstruction of the Papal Employment of the Title Pontifex Maximus. JRH 41,3: 312-325. Online at http://onlinelibrary.wiley.com/doi/10.1111/1467-9809.1240o/full/.

Dunn, G. 2007. Cyprian and the Bishops of Rome: Questions of Primacy in the Early Church. Srathfield, Australia: St. Paul's. 
Dunn, G. 2002. Cyprian of Carthage and the Episcopal Synod of 254. REA 48: 229-47. Edwards, M. J. 2015. Religions of the Roman Empire. Oxford: Oxford University Press. Grabbe, L. L. 2010. An Introduction to Second Temple Judaism: History and Religion of the Jews in the Time of Nehemiah, the Maccabees, Hillel and Jesus. London: T\&T Clark.

Gwynn, D. 2012. Episcopal Leadership. In The Oxford Handbook of Late Antiquity, ed. S. F. Johnson, 876-915. Oxford: Oxford University Press.

Haeperen van, F. 2003. De pontifes païens aux pontifes chrétiens: transformations d'un titre. Revue Belge de Philologie et d'Histoire 81: 137-59.

Heid, S. 2007. The Romanness of Roman Christianity, in A Companion to Roman Religion, ed. J. Rüpke, 406-28. Oxford: Blackwell.

Humfress, C. 2000. Roman Law, Forensic Argument and the Formation of Christian Orthodoxy (III-VI Centuries). In Orthodoxie, christianisme, histoire: Orthodoxy, Christianity, History, ed. S. Elm, E. Rebillard \& A. Romano. Roma: École française de Rome.

Kajanto, I. 1981. Pontifex Maximus as the Title of the Pope. Arctos 15: 37-52.

Maccarone, M. 1991. 'sedes Apostolica - Vicarius Petri'. La perpetuità del primate di Pietro nella sede e nel vescovo di Roma, in Il pimato del vescovo di Roma nel primo millennio: ricerche e testimonianze, ed. M. Maccarone, 276-362. Città del Vaticano: Libreria Editrice Vaticana.

Millar, F. G. B. 1977. The Emperor in the Roman World. London: Duckworth.

Millar, F. G. B. 1971. Paul of Samosata, Zenobia and Aurelian: the Church, Local Culture and Political Allegiance in Third-Century Syria.JRS 61: 1-17.

Pietri, Ch. 1991. La conversion de Rome et la primauté du pape (IV-VI e s.) In Il primato del vescovo di Roma nel primo millennio, ed. M. Maccarone, 219-43. Città del Vaticano: Libreria Editrice Vaticana.

Pietri, Ch. 1976. Roma Christiana: recherches sur l'Eglise de Rome, son organisation, sa politique, son idéologie de Miltiade à Sixte III (311-440). Roma: École française de Rome.

Rüpke, J. 2014. From Jupiter to Christ. Oxford: Oxford University Press.

Sanders, E. P. 1992. Judaism: Practice and Belief, 63 BCE-66 CE. London: SCM Press.

Schürer, E. 1979. A History of the Jewish People in the Time of Jesus Christ, volume 2. Edinburgh: T\&T Clark.

Still, T. Images of Peter in the Apostolic Fathers. In: Peter in Early Christianity ed. H. K. Bond and L. W. Hurtado, 161-7. Grand Rapids, Michigan: Eerdmans.

Thompson, G. L. 2015. The pax constantiniana and the Roman Episcopate. In The Bishop of Rome in Late Antiquity, 17-36. Farnham: Ashgate.

Trout, D. 2015. Damasus of Rome: The Epigraphic Poetry. Introduction, Texts, Translations, and Commentary. Oxford: Oxford University Press.

Vermes, G. 2003. Jesus in his Jewish Context. London: SCM Press.

Watson, A. 1999. Aurelian and the Third Century. London: Routledge.

Zwierlein, O. 2010. Petrus in Rom: die literarischen Zeugnisse. Berlin: De Gruyter. 